\section{The Potential Use of Photoperiod during Transplant Production under Artificial Lighting Conditions on Floral Development and Bolting, Using Spinach as a Model}

\author{
Hyeon-Hye Kim ${ }^{1}$, Changhoo Chun ${ }^{2}$, and Toyoki Kozai ${ }^{3}$ \\ Department of Biological Science, Faculty of Horticulture, Chiba University, \\ Matsudo, 271-8510, Japan
}

\author{
Junya Fuse \\ Agricultural Development Department, Taiyo Kogyo Company, Ltd., Tokyo, \\ 111-0053, Japan
}

Additional index words. closed system, hydroponics, Spinacia oleracea

\begin{abstract}
Spinach (Spinacia oleracea L.) was chosen to demonstrate that the respective vegetative or reproductive conditions of transplants can be controlled in their early stages of development under artificial light in a closed system. Transplant production under artificial light was divided into three growth phases and the photoperiod during each of these phases was varied. The rate of floral development was controlled by photoperiod, but floral initiation itself was not affected. Short photoperiod treatments (8 or 12 hours/day) retarded floral development and stem elongation (bolting). This delay continued even after the transplants were transferred to natural long-day (15.5 hours/day on average) conditions with high temperatures $\left(17\right.$ and $37^{\circ} \mathrm{C}$ minimum and maximum). We concluded that by using short photoperiods during transplant production, marketable plants with reduced bolting could be produced under natural long-day conditions. In Japan, spinach with this rosetting capacity would be of greater value. Further, this concept opens the possibility of producing better quality transplants of several species under artificial lighting conditions of appropriate length, and thereby controlling their floral development and/or bolting.
\end{abstract}

The commercial possibilities of producing various transplant species under artificial light in a closed system have been discussed by Kozai (1998). In such a system, vegetative or reproductive responses could be controlled relatively easily by photoperiod with a minimum increase in production cost. For example, the value of certain species of transplants increases when bolting and/or flower bud initiation has been controlled environmentally. In the present study, spinach was chosen to demonstrate this concept.

Spinach production in hydroponic greenhouses is becoming popular in Japan (Chun et al., 1999). The transplants are produced under one set of environmental conditions, then transplanted to another greenhouse production area,

Received for publication 28 Dec. 1998. Accepted for publication 6 May 1999. We thank Katsuyoshi Okabe and Akira Yoshie, Taiyo Kogyo Co., Ltd., for their helpful advice. The cost of publishing this paper was defrayed in part by the payment of page charges. Under postal regulations, this paper therefore must be hereby marked advertisement solely to indicate this fact.

${ }^{1}$ Postdoctoral Research Associate. Address after Aug. 1999: Dept. of Horticulture, Michigan State Univ., E. Lansing, MI 48824-1325.

${ }^{2}$ Associate Professor.

${ }^{3}$ Professor. with different conditions, for the final stages of growth. Thus, plants are produced under two different environmental regimes.

Spinach, our model plant, naturally develops a rosette of leaves soon after germination. This short stem begins to elongate as the plant matures (Singhal and Kulkarni, 1998). When spinach is grown under the long-day conditions of spring/summer, plants have a greater tendency to bolt and flower (Hartmann et al., 1988; Singhal and Kulkarni, 1998). Chun et al. (1999) showed that manipulating the day length and temperature during transplant production prevented bolting. In our study, the effect of photoperiod on floral development and bolting of transplants produced under artificial lighting conditions was investigated, since few studies have been conducted on the physiological aspects of spinach transplants produced under such conditions.

\section{Materials and Methods}

Five seeds of spinach (cv. Dimple; Sakata Seed Corp., Yokohama, Japan) were sown in each cell $\left(8 \mathrm{~cm}^{3}\right)$ of trays (144 cells per tray, 30 $\times 60 \mathrm{~cm}$; Taiyo Kogyo Co., Ltd., Tokyo). Cells were filled with granules of rock wool $(3 \mathrm{~g}$ per cell; Nichias Corp., Tokyo) on 20 May. They were cultured in three growth chambers (Koitotron 3HN-35MLA; Koito Industries,
Ltd., Yokohama, Japan), under a microwavepowered lamp (Solar 1000 ${ }^{\mathrm{TM}}$ Lighting System SAB; Fusion Lighting, Rockville, Md.) as described by Kozai et al. (1994). The photosynthetic photon flux $(P P F)$ on the surface of the trays was $350 \pm 50 \mu \mathrm{mol} \cdot \mathrm{m}^{-2} \cdot \mathrm{s}^{-1}$. Light/ dark periods in the chambers were $8 / 16,12 / 12$, and 16/8 h/day, respectively. Air temperature and relative humidity throughout the day in each growth chamber were set at $20^{\circ} \mathrm{C}$ and $70 \%$, respectively.

Growth in these environmental chambers was divided into three phases: Phase A, from sowing to cotyledon expansion (6d); Phase B, from cotyledon expansion to expansion of two true leaves ( $8 \mathrm{~d}$ ); and Phase $\mathrm{C}$, expansion of two true leaves to expansion of four true leaves ( $3 \mathrm{~d}$ ), for a total of $17 \mathrm{~d}$. A total of 15 different photoperiodic treatments were used.

Fertigation was conducted daily, using a commercial nutrient solution (High Tempo; Sumitomo Chemical Co., Ltd., Tokyo, Japan). The solution contained $12.0 \mathrm{mmol} \cdot \mathrm{L}^{-1} \mathrm{NO}_{3}-\mathrm{N}$, $0.8 \mathrm{mmol} \cdot \mathrm{L}^{-1} \mathrm{NH}_{4}-\mathrm{N}, 30.6 \mathrm{mmol} \cdot \mathrm{L}^{-1} \mathrm{P}, 7.3$ $\mathrm{mmol} \cdot \mathrm{L}^{-1} \mathrm{~K}, 10.2 \mathrm{mmol} \cdot \mathrm{L}^{-1} \mathrm{Ca}$, and 4.2 $\mathrm{mmol} \cdot \mathrm{L}^{-1} \mathrm{Mg}$. The $\mathrm{pH}$ and electrical conductivity (EC) of the nutrient solution were 6.0 and $140 \mathrm{mS} \cdot \mathrm{m}^{-1}$, respectively.

On 6 June the seedlings were transplanted to a plastic greenhouse and cultured for $14 \mathrm{~d}$ under natural lighting conditions. The natural day length from 6 to 20 June averaged $15.5 \mathrm{~h} /$ day (lat. $35^{\circ} \mathrm{N}$ ) and air temperature averaged $24^{\circ} \mathrm{C}\left(17\right.$ and $37^{\circ} \mathrm{C}$ minimum and maximum $)$. These transplants were grown in an ebb-andflow technique hydroponic system (188 Type; Ibikawa Kogyo Co., Ogaki, Japan) at a planting density of 300 plants $/ \mathrm{m}^{2}$. Throughout the experiment, the nutrient solution's $\mathrm{pH}$ and EC were maintained at 6.0 and $280 \mathrm{mS} \cdot \mathrm{m}^{-1}$, respectively. Plants were harvested on 20 June.

Before the seedlings were transplanted from the growth chamber, five transplants from each treatment were destructively sampled to determine the stage of floral development. Meristems were viewed and photographed using a digital microscope (VH-6300; Keyence Corp., Osaka, Japan). Leaf and root lengths and shoot and root fresh weights were also determined. At final harvest maximum length of stem and leaf, number of leaves, and shoot fresh weight were recorded. Treatments were arranged in a randomized complete-block design with three replications of 15 plants each per treatment. Analysis of variance and Duncan's multiple range test were used for a statistical comparison among the treatments.

Floral development of a terminal apical meristem can be divided into four stages, according to Eguchi and Ichikawa (1940). The vegetative state (no floral differentiation) was characterized by a flat shoot apex with only subtending leaf primordia. Flower cluster initiation began (Fig. $1 \mathrm{~A}$ and a) when the apex formed a hemispherical dome. The diameter of the dome enlarged steadily during the flower cluster differentiation stage (Fig. $1 \mathrm{~B}$ and b). During the flower cluster formation stage, many flower clusters and bracts were formed (Fig. $1 \mathrm{C}$ and c). 

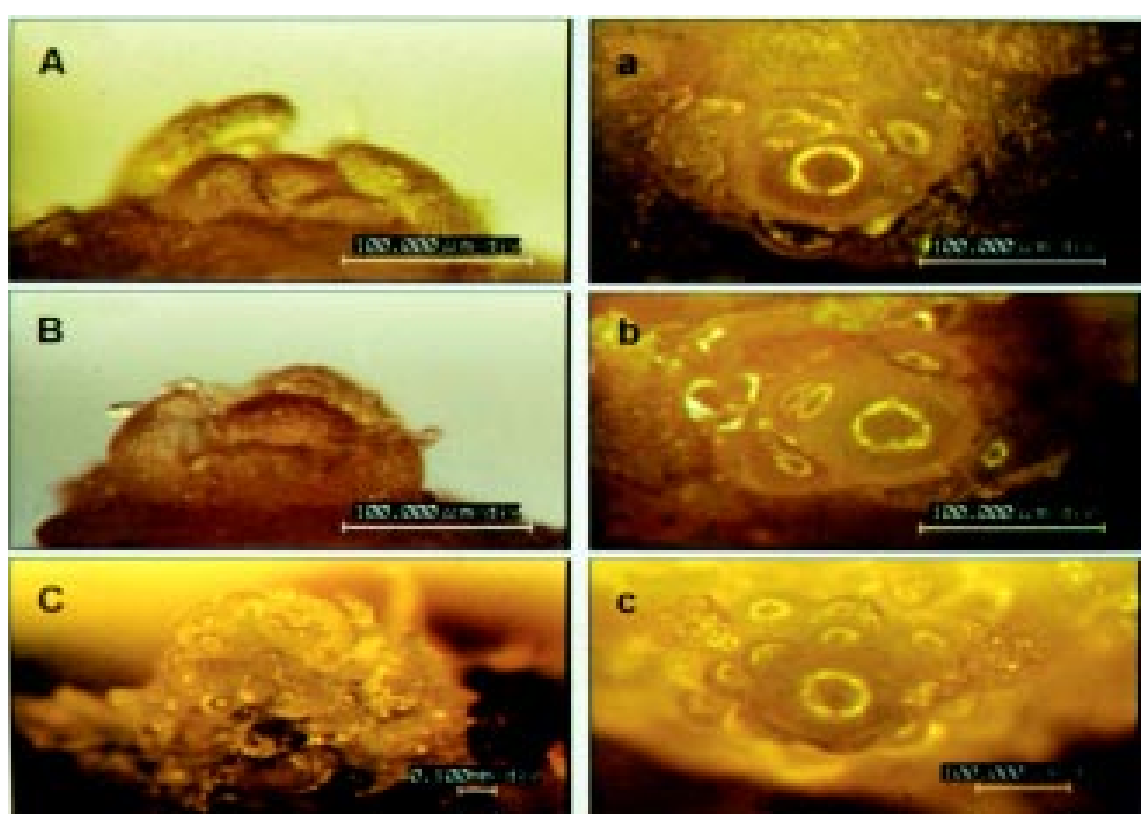

Fig. 1. Digital micrographs of Spinach apical meristems which were used as standard observation data. Flower cluster initiation (A), differentiation $(\mathbf{B})$, and formation $(\mathbf{C})$ stages of transplants grown under different photoperiod conditions for $17 \mathrm{~d}$ (left column: side view, right column: top view).

\section{Results}

Floral development was most rapid in treatments 16-16-8 and 16-16-16, in which all the terminal apical meristems were in the flower cluster formation stage (Table 1, Fig. $1 \mathrm{C}$ and c). In treatments 8-16-8 and 8-16-16, apices were between the flower cluster differentiation and flower cluster formation stages, with the latter being dominant. Floral development in the remaining treatments was retarded. In treatments $8-8-12,8-8-16,8-12-12,12-8-12$, $12-12-8,12-12-12,16-8-8$, and 16-8-16, differentiation had occurred, whereas in treatments $8-8-8,8-12-8$, and $12-8-8$, initiation was common (Table 1).

Seventeen days after sowing the maximum leaf length, maximum root length, and shoot fresh and dry weights did not show a consistent trend among the treatments (Table 2). For every growth measured, except for leaf length, treatment 16-16-16 showed the greatest vegetative growth (Table 2).

At the final harvest (14 d after transplanting) stem lengths were greatest in treatments 8-16-16 and 16-16-16 (17.2 and $21.1 \mathrm{~cm}$, respectively). Stem lengths were $>10 \mathrm{~cm}$ in treatments 8-16-8, 8-16-16, 16-16-8, and 1616-16, for which the Phase B photoperiod was $16 \mathrm{~h}$, whereas they were $<10 \mathrm{~cm}$ in treatments 8-8-16 $(6.6 \mathrm{~cm})$ and 16-8-16 $(7.9 \mathrm{~cm})$, where the Phase $\mathrm{B}$ photoperiod was $8 \mathrm{~h}$ and the Phase $\mathrm{C}$ photoperiod was $16 \mathrm{~h}$ (Table 3 ).

Leaf lengths were significantly shorter in treatments 8-16-16, 16-16-8, and 16-16-16 than in other treatments, whereas they were longer than $25 \mathrm{~cm}$ in treatments $8-8-8,8-8-12$, $8-12-12,12-8-8,12-12-8,12-12-12$, and 16-88 . The number of leaves and the shoot fresh and dry weights did not vary consistently among the treatments (Table 3).
True floral development was more rapid under treatments in which the photoperiod was $16 \mathrm{~h}$ during Phase $\mathrm{B}$, regardless of the photoperiod in Phase C. Floral development was retarded in other treatments. These results suggest that the rate of floral development can be controlled by photoperiod, although floral initiation itself cannot. In most plants, once the transformation from the vegetative to the reproductive state has been made, the process is irreversible and the respective floral parts will continue to develop until anthesis if there is an appropriate carbon source, even though the environmental conditions that existed during floral initiation have changed (Janick, 1986).

Prior to transplanting seedlings were visually similar, regardless of treatment; however, there were anatomical differences among the apical meristems. Root fresh and dry weights were greater in the long photoperiod treatments, and root growth was proportional to the total daily light integral. This has also been observed in wheat (Triticum aestivum L.) (MacDowall, 1977). Apparently, the light compensation point for root growth is higher than that for shoot growth (MacDowall, 1972a, $1972 b, 1972 c)$. This is attributed to a sourcesink relationship; the primary sink is the leaves, then stems if photosynthate is limited. At light saturation, the roots become the primary sink (MacDowall, 1973). Bruggink(1992) reported that relative growth rate in Lycopersicon and Dianthus was proportional to the level of mean daily light integral.

At final harvest stems were longer in plants exposed to long photoperiods before transplanting. Leaf lengths, however, were shorter. Inhibition of floral development resulted in retarded bolting.

All treatments with 8- or 12-h photoperiods in Phase B, regardless of the photoperiod in Phases A and C, retarded bolting, and the resulting plants were commercially acceptable for the Japanese market. This suggests that short photoperiod treatments before transplanting, which retarded floral development, also retarded bolting. This retardation occurred even though the environmental conditions were changed to the natural long days and high temperatures of summer, under which spinach easily bolts and becomes unmarketable.
Table 1. Effect of photoperiod on floral development in Spinach transplants $17 \mathrm{~d}$ after sowing.

\begin{tabular}{lcccc}
\hline \hline & \multicolumn{3}{c}{ No. of transplants at the respective stage of floral development (Fig. 1) } \\
\cline { 2 - 5 } $\begin{array}{l}\text { Treatment } \\
\text { codes }^{z}\end{array}$ & $\begin{array}{c}\text { No } \\
\text { differentiation }\end{array}$ & $\begin{array}{c}\text { Flower cluster } \\
\text { initiation }\end{array}$ & $\begin{array}{c}\text { Flower cluster } \\
\text { differentiation }\end{array}$ & $\begin{array}{c}\text { Flower cluster } \\
\text { formation }\end{array}$ \\
\hline $8-8-8$ & & 4 & 1 & \\
$8-8-12$ & 1 & 1 & 4 & \\
$8-8-16$ & 1 & 4 & 3 & 4 \\
$8-12-8$ & 1 & 1 & 4 & 4 \\
$8-12-12$ & & & 1 & \\
$8-16-8$ & & 3 & 1 & \\
$8-16-16$ & & 1 & 2 & \\
$12-8-8$ & & 1 & 4 & \\
$12-8-12$ & & 1 & 3 & 5 \\
$12-12-8$ & & 1 & 4 & \\
$12-12-12$ & & 1 & 4 & \\
$16-8-8$ & & & & \\
$16-8-16$ & & & & \\
$16-16-8$ & & & & \\
$16-16-16$ & & & & \\
\hline
\end{tabular}

${ }^{\mathrm{z}}$ The three numbers refer to the photoperiods in Phases A, B, and C. 
Table 2. Effect of photoperiod on leaf and root lengths, shoot and root fresh weights, and shoot and root dry weights of spinach transplants $17 \mathrm{~d}$ after sowing.

\begin{tabular}{|c|c|c|c|c|c|c|}
\hline \multirow{2}{*}{$\begin{array}{l}\text { Treatment } \\
\text { codes }^{z}\end{array}$} & \multirow{2}{*}{$\begin{array}{c}\text { Leaf } \\
\text { length } \\
(\mathrm{cm})\end{array}$} & \multirow{2}{*}{$\begin{array}{l}\text { Root } \\
\text { length } \\
(\mathrm{cm})\end{array}$} & \multicolumn{2}{|c|}{ Fresh wt (mg) } & \multicolumn{2}{|c|}{ Dry wt (mg) } \\
\hline & & & Shoot & Root & Shoot & Root \\
\hline $8-8-8$ & $7.4 b^{y}$ & $5.5 \mathrm{a}$ & $290 \mathrm{ab}$ & $400 \mathrm{bc}$ & $19.4 \mathrm{c}$ & $\overline{4.4 b-d}$ \\
\hline $8-8-12$ & $7.3 \mathrm{bc}$ & $5.4 \mathrm{a}$ & $300 \mathrm{ab}$ & $400 \mathrm{bc}$ & $26.4 \mathrm{a}-\mathrm{c}$ & $3.8 \mathrm{~cd}$ \\
\hline $8-8-16$ & $7.2 \mathrm{bc}$ & $5.5 \mathrm{a}$ & $280 \mathrm{ab}$ & $600 \mathrm{bc}$ & $30.1 \mathrm{a}-\mathrm{c}$ & $8.0 \mathrm{~b}-\mathrm{d}$ \\
\hline $8-12-8$ & $7.8 \mathrm{a}-\mathrm{c}$ & $5.0 \mathrm{a}$ & $300 \mathrm{ab}$ & $400 \mathrm{bc}$ & $23.2 \mathrm{bc}$ & $4.2 \mathrm{~b}-\mathrm{d}$ \\
\hline $8-12-12$ & $6.5 \mathrm{c}$ & $5.2 \mathrm{a}$ & $290 \mathrm{ab}$ & $800 \mathrm{~b}$ & $26.9 \mathrm{a}-\mathrm{c}$ & $7.9 \mathrm{~b}-\mathrm{d}$ \\
\hline $8-16-8$ & $6.9 \mathrm{bc}$ & $5.3 \mathrm{a}$ & $280 \mathrm{ab}$ & $700 \mathrm{bc}$ & $23.7 \mathrm{bc}$ & $7.9 \mathrm{~b}-\mathrm{d}$ \\
\hline $8-16-16$ & $7.3 \mathrm{bc}$ & $4.8 \mathrm{a}$ & $390 \mathrm{ab}$ & $900 \mathrm{ab}$ & $47.1 \mathrm{ab}$ & $11.4 \mathrm{bc}$ \\
\hline $12-8-8$ & $9.0 \mathrm{a}$ & $5.5 \mathrm{a}$ & $400 \mathrm{a}$ & $500 \mathrm{bc}$ & $26.8 \mathrm{a}-\mathrm{c}$ & $4.7 b-d$ \\
\hline $12-8-12$ & $7.0 \mathrm{bc}$ & $5.5 \mathrm{a}$ & $350 \mathrm{ab}$ & $500 \mathrm{bc}$ & $30.4 \mathrm{a}-\mathrm{c}$ & $5.7 b-d$ \\
\hline $12-12-8$ & $7.0 \mathrm{bc}$ & $5.5 \mathrm{a}$ & $240 \mathrm{~b}$ & $500 \mathrm{bc}$ & $41.9 \mathrm{a}-\mathrm{c}$ & $5.4 \mathrm{~b}-\mathrm{d}$ \\
\hline $12-12-12$ & $6.4 \mathrm{c}$ & $4.9 \mathrm{a}$ & $240 \mathrm{~b}$ & $600 \mathrm{bc}$ & $24.3 \mathrm{bc}$ & $7.8 \mathrm{~b}-\mathrm{d}$ \\
\hline $16-8-8$ & $8.1 \mathrm{ab}$ & $4.0 \mathrm{~b}$ & $280 \mathrm{ab}$ & $300 \mathrm{c}$ & $19.9 \mathrm{c}$ & $3.2 \mathrm{~d}$ \\
\hline $16-8-16$ & $7.4 \mathrm{bc}$ & $5.1 \mathrm{a}$ & $320 \mathrm{ab}$ & $800 \mathrm{bc}$ & $36.4 \mathrm{a}-\mathrm{c}$ & $11.8 \mathrm{~b}$ \\
\hline $16-16-8$ & $7.2 \mathrm{bc}$ & $5.2 \mathrm{a}$ & $340 \mathrm{ab}$ & $700 \mathrm{bc}$ & $28.4 \mathrm{a}-\mathrm{c}$ & $10.7 \mathrm{~b}-\mathrm{d}$ \\
\hline $16-16-16$ & $7.3 \mathrm{bc}$ & $5.5 \mathrm{a}$ & $420 \mathrm{a}$ & $130 \mathrm{a}$ & $49.5 \mathrm{a}$ & $21.7 \mathrm{a}$ \\
\hline
\end{tabular}

${ }^{2}$ The three numbers refer to the photoperiods in Phases A, B, and C.

${ }^{y}$ Mean separation within columns by Duncan's multiple range test, $P \leq 0.05$.

Table 3. Effect of photoperiod during transplant production on stem and leaf lengths, number of leaves, and shoot fresh and dry weights of spinach transplants $14 \mathrm{~d}$ after transplanting ( $31 \mathrm{~d}$ after sowing).

\begin{tabular}{|c|c|c|c|c|c|}
\hline \multirow[b]{2}{*}{$\begin{array}{l}\text { Treatment } \\
\text { codes }^{2}\end{array}$} & \multirow{2}{*}{$\begin{array}{c}\text { Stem } \\
\text { length } \\
(\mathrm{cm})\end{array}$} & \multirow{2}{*}{$\begin{array}{c}\text { Leaf } \\
\text { length } \\
(\mathrm{cm})\end{array}$} & \multirow{2}{*}{$\begin{array}{c}\text { No. } \\
\text { of } \\
\text { leaves }\end{array}$} & \multicolumn{2}{|c|}{ Shoot } \\
\hline & & & & $\begin{array}{c}\text { Fresh } \\
(\mathrm{g})\end{array}$ & $\begin{array}{l}\text { Dry } \\
(\mathrm{mg})\end{array}$ \\
\hline $8-8-8$ & $4.5 \mathrm{~d}^{\mathrm{y}}$ & $27.7 \mathrm{a}$ & $13.8 \mathrm{a}-\mathrm{c}$ & $13.12 \mathrm{a}$ & $577 \mathrm{ab}$ \\
\hline $8-8-12$ & $3.4 \mathrm{~d}$ & $25.9 \mathrm{ab}$ & $12.4 \mathrm{~b}-\mathrm{d}$ & $10.50 \mathrm{a}-\mathrm{d}$ & $531 \mathrm{a}-\mathrm{c}$ \\
\hline $8-8-16$ & $6.6 \mathrm{~b}-\mathrm{d}$ & $23.8 \mathrm{~b}-\mathrm{d}$ & $11.2 \mathrm{~cd}$ & $7.76 \mathrm{c}-\mathrm{e}$ & $422 \mathrm{bc}$ \\
\hline $8-12-8$ & $8.5 b-d$ & $24.0 \mathrm{~b}-\mathrm{d}$ & $12.0 \mathrm{~b}-\mathrm{d}$ & $6.90 \mathrm{c}-\mathrm{e}$ & $346 \mathrm{c}$ \\
\hline $8-12-12$ & $8.2 \mathrm{~b}-\mathrm{d}$ & $25.7 \mathrm{a}-\mathrm{c}$ & $12.4 \mathrm{~b}-\mathrm{d}$ & $8.86 \mathrm{~b}-\mathrm{e}$ & $427 \mathrm{bc}$ \\
\hline $8-16-8$ & $10.5 \mathrm{bc}$ & $22.1 \mathrm{~d}$ & $12.8 \mathrm{a}-\mathrm{d}$ & $7.68 \mathrm{c}-\mathrm{e}$ & 394 bc \\
\hline $8-16-16$ & $17.2 \mathrm{a}$ & $19.9 \mathrm{f}$ & $15.0 \mathrm{ab}$ & $10.32 \mathrm{a}-\mathrm{d}$ & $482 \mathrm{a}-\mathrm{c}$ \\
\hline $12-8-8$ & $4.5 \mathrm{~d}$ & $25.2 \mathrm{a}-\mathrm{d}$ & $12.0 \mathrm{~b}-\mathrm{d}$ & $8.28 \mathrm{c}-\mathrm{e}$ & $390 \mathrm{bc}$ \\
\hline $12-8-12$ & $7.1 \mathrm{~b}-\mathrm{d}$ & $22.4 \mathrm{~cd}$ & $12.8 \mathrm{a}-\mathrm{d}$ & $8.06 \mathrm{c}-\mathrm{e}$ & $327 \mathrm{c}$ \\
\hline $12-12-8$ & $4.8 \mathrm{~cd}$ & $25.3 \mathrm{a}-\mathrm{d}$ & $10.6 \mathrm{~d}$ & $6.86 \mathrm{c}-\mathrm{e}$ & $333 \mathrm{c}$ \\
\hline $12-12-12$ & $8.2 \mathrm{~b}-\mathrm{d}$ & $27.0 \mathrm{ab}$ & $13.0 \mathrm{a}-\mathrm{d}$ & $10.70 \mathrm{a}-\mathrm{c}$ & $478 \mathrm{a}-\mathrm{c}$ \\
\hline $16-8-8$ & $7.5 \mathrm{~b}-\mathrm{d}$ & $25.7 \mathrm{a}-\mathrm{c}$ & $12.6 \mathrm{~b}-\mathrm{d}$ & $12.18 \mathrm{ab}$ & $634 \mathrm{a}$ \\
\hline $16-8-16$ & $7.9 \mathrm{~b}-\mathrm{d}$ & $24.6 \mathrm{a}-\mathrm{d}$ & $11.6 \mathrm{~cd}$ & $8.46 \mathrm{~b}-\mathrm{e}$ & $401 \mathrm{bc}$ \\
\hline $16-16-8$ & $11.7 \mathrm{~b}$ & $21.3 \mathrm{e}$ & $13.6 \mathrm{a}-\mathrm{d}$ & $8.90 \mathrm{~b}-\mathrm{e}$ & $495 \mathrm{a}-\mathrm{c}$ \\
\hline $16-16-16$ & $21.1 \mathrm{a}$ & $14.3 \mathrm{~g}$ & $15.8 \mathrm{a}$ & $5.48 \mathrm{e}$ & $338 \mathrm{c}$ \\
\hline
\end{tabular}

${ }^{2}$ The three numbers refer to the photoperiods in Phases A, B, and C.

yean separation within columns by Duncan's multiple range test, $P \leq 0.05$.

Spinach is grown for its rosette leaves, which are harvested when they are nearly fully expanded (Hartmann et al., 1988). Increased yields (shoot fresh weight and number of leaves) were obtained in plants exposed to 8or 12 -h photoperiods prior to transplanting. In this experiment, regardless of photoperiod after the above sensitive growth period, the best time for harvest was $14 \mathrm{~d}$ after transplanting, when the maximum leaf length was $\approx 25 \mathrm{~cm}$.

Transplants grown under short photoperiods showed negligible bolting and maintained marketability. This suggests that marketable transplants can be produced under short photoperiods using artificial light, even if seedlings are subsequently transferred to natural long-day conditions. These findings are comparable with those reported by Chun et al. (1999). Further, spinach should be considered a day-neutral plant in respect to floral initiation, although it is a quantitative long-day plant in its floral development.

Using short photoperiods during early development may permit production of highquality transplants of other species, such as Lactuca, Brassica, and Allium.

\section{Literature Cited}

Boswell, R. 1935. Studies of the temperature, day length and development interrelations of spinach varieties in the field. Proc. Amer. Soc. Hort. Sci. 32:549-557.

Bruggink, G.T. 1992. A comparative analysis of the influence of light on growth of young tomato and carnation plants. Scientia Hort. 51:71-81.

Chun, C., K. Kozai, C. Kubota, and K. Okabe. 1999. Manipulation of bolting and flowering in spinach (Spinacia oleracea L.) transplant production system using artificial light. Acta Hort. (In press).

Eguchi, T. and H. Ichikawa. 1940. Studies on the flower bud development and bolting of spinach (in Japanese). J. Jpn. Soc. Hort. Sci. 11:13-56.

Garner, W.W. and H.A. Allard. 1920. Effect of the relative length of day and night and other factors of the environment on growth and reproduction in plants. J. Agr. Res. 18:553-606.

Hartmann, H.T., A.M. Kofranek, V.E. Rubatzky, and W.J. Flocker. 1988. Plant science. PrenticeHall, Englewood Cliffs, N.J.

Janick, J. 1986. Horticultural science. W.H. Freeman, New York.

Kozai, T. 1998. Transplant production under artificial light in closed systems, p. 296-308. In: Proc. $3^{\text {rd }}$ Asian Crop Sci. Conf., Taiwan.

Kozai, T., Y. Kitaya, and Y.S. Oh. 1994. Microwave-powered lamp as a high intensity light source for plant growth. Acta Hort. 399:107112

MacDowall, F.D.H. 1972a. Growth kinetics of Marquis wheat. I. Light dependence. Can. J. Bot. 50:89-99.

MacDowall, F.D.H. 1972b. Growth kinetics of Marquis wheat. II. Carbon dioxide dependence. Can. J. Bot. 50:883-889.

MacDowall, F.D.H. 1972c. Growth kinetics of Marquis wheat. III. Nitrogen dependence. Can. J. Bot. 50:1749-1761.

MacDowall, F.D.H. 1973. Growth kinetics of Marquis wheat. IV. Temperature dependence. Can. J. Bot. 51:729-736.

MacDowall, F.D.H. 1977. Growth kinetics of Marquis wheat. VII. Dependence on photoperiod and light compensation point in vegetative phase. Can. J. Bot. 55:639-643.

Magruder, R. and H.A. Allard. 1936. The effect of controlled photoperiod on the production of seed stalks in eight varieties of spinach. Proc. Amer. Soc. Hort. Sci. 34:502-506.

Metzger, J.D. and J.A.A. Zeevaart. 1980. Effect of photoperiod on the levels of endogenous gibberellins in spinach as measured by combined gas chromatography-selected ion current monitoring. Plant Physiol. 66:844-846.

Singhal, R.S. and P.R. Kulkarni. 1998. Leafy vegetables, p. 533-588. In: D.K. Salunkhe and S.S. Kadam (eds.). Handbook of vegetable science and technology: Production, composition, storage, and processing. Marcel Dekker, New York.

Zeevaart, J.A.D. 1971. Effects of photoperiod on growth rate and endogenous gibberellins in the long-day rosette plant spinach. Plant Physiol. $47: 821-827$. 